\title{
Vaporization, Sublimation Enthalpy, and Crystal Structures of Imidazo[1,2-a]pyrazine and Phthalazine
}

\author{
Massiel Mori, Nigam Rath, Chase Gobble, and James Chickos* \\ Department of Chemistry and Biochemistry, University of Missouri-St. Louis, St. Louis, Missouri 63121, United States
}

Artemiy A. Samarov

Department of Chemical Thermodynamics and Kinetics, St. Petersburg State University, St. Petersburg 199034, Russia

\author{
Sergey P. Verevkin \\ Department of Physical Chemistry, University of Rostock, Rostock 18051, Germany
}

Supporting Information

\begin{abstract}
The vaporization enthalpy of imidazo[1,2-a]pyrazine is evaluated by correlation gas chromatography using two sets of standards and by transpiration. Vaporization enthalpies were evaluated using heterocyclic standards with dipole moments that vary from 0 to $3.0 \mathrm{D}$ and using standards with dipole moments $>3.0 \mathrm{D}$. A value of $(70.7 \pm 1.0) \mathrm{kJ} \cdot \mathrm{mol}^{-1}$ measured by transpiration compares to $(67.9 \pm 1.4) \mathrm{kJ} \cdot \mathrm{mol}^{-1}$ measured by correlation gas chromatography using standards characterized by dipole moments $>3.0 \mathrm{D}$. The results suggest that imidazo[1,2-a]pyrazine is a member of this series of compounds whose vaporization enthalpies exceed those less polar heterocycles by a fairly constant amount, $(6.9 \pm 0.3) \mathrm{kJ} \cdot \mathrm{mol}^{-1}$, in this case by $(5.9 \pm 3.0) \mathrm{kJ} \cdot \mathrm{mol}^{-1}$ using the less polar heterocycles. The crystal structures of phthalazine, another member of the polar series, and of imidazo[1,2-a]pyrazine were determined to examine whether $\pi-\pi$ stacking, present in the solid state of two other members of the polar series, was a characteristic of this series. If present in the liquid, $\pi-\pi$ stacking could offer a possible explanation for the vaporization enthalpy differences observed. The sublimation enthalpy of imidazo[1,2-a]pyrazine was also evaluated.
\end{abstract}

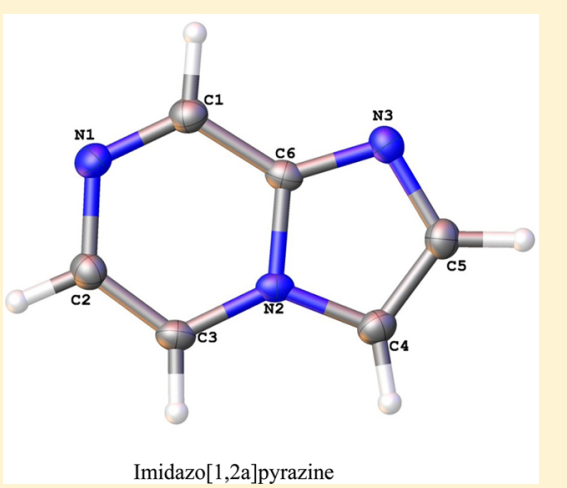

\section{INTRODUCTION}

Structure plays a key role in enzyme inhibition although many other factors influence efficacy. These include lipophilicity, hydrogen bonding, and polarity. The latter is frequently influenced by electronic effects mediated by substituents and conjugation. In the course of evaluating the vaporization enthalpies of a series of heterocycles by correlation gas chromatography, we have observed that certain heterocycles have unusually stronger intermolecular interactions with themselves and presumably with other polar substances than related substances with similar structures. ${ }^{1}$ Using dipole moment as a criterion of polarity, enthalpies of transfer from the stationary phase of the column to the gas phase, $\Delta_{\text {trans }} H_{m}\left(T_{m}\right)$, as measured by gas chromatography were found to correlate linearly with their respective vaporization enthalpies for a series of heterocycles with dipole moments that varied from 0 to approximately $3.0 \mathrm{D}$, whereas molecules with dipole moments $>3.0 \mathrm{D}$ were found to be outliers in these correlations. The enthalpies of transfer of the outliers themselves, did correlate linearly with their respective vaporization enthalpies when correlated in a similar manner. Vaporization enthalpy differences between the two sets of substances differed by $(6.9 \pm 0.3) \mathrm{kJ} \cdot \mathrm{mol}^{-1}$.
Materials previously examined with dipole moments $<3.0 \mathrm{D}$ included, pyrazine (1), pyrimidine (2), 2- $\mathrm{N}, \mathrm{N}$-dimethylaminopyridine (3), 1,5-diazobicyclo[4.30]non-5-ene (4), and others. Compound with dipole moments $>3.0$ included 1-methylimidazole (7), pyridazine (8) and 4- $\mathrm{N}, \mathrm{N}$-dimethylaminopyridine (9), and 1,5-diazabicyclo[4.3.0] non-5-ene (10), among others. ${ }^{1-3}$ The structures of a number of these materials are provided in Figure 1. As noted in the legend, the top row of closely related structures consists of compounds whose enthalpy of transfer and corresponding vaporization enthalpy correlated linearly with each other and with those of other similar substances characterized with dipole moments $<3.0 \mathrm{D}$, whereas the bottom row consists of compounds characterized with dipole moments $>3.0 \mathrm{D}$. The enthalpies of transfer and corresponding vaporization enthalpies of the latter materials correlated with others possessing similar polarities.

We have observed that derivatives of many of the parent compounds characterized by dipole moments $>3 \mathrm{D}$ are frequently

Received: July 16, 2015

Accepted: November 4, 2015

Published: December 3, 2015 
<smiles>c1cnccn1</smiles><smiles>c1cncnc1</smiles>

1<smiles>CN(C)c1ccccn1</smiles>

3<smiles>C1CN=C2CCCN2C1</smiles>

4<smiles>C1CCCN2CCCN=C2CC1</smiles>

5<smiles>c1ccc2ncncc2c1</smiles><smiles>Cn1ccnc1</smiles>

8<smiles>CN(C)c1ccncc1</smiles><smiles>c1ccn2ccnc2c1</smiles>

10<smiles>c1cnc2ncnn2c1</smiles>

11<smiles>c1ccc2cnncc2c1</smiles>

12

13

Figure 1. Top row: pyrazine (1), pyrimidine (2), 2-N,N-dimethylaminopyridine (3), 1,5-diazobicyclo[4.30]non-5-ene (4), 1,8-diazabicyclo[5.4.0]undec-7-ene (5) and quinazoline (6); a series of heterocycles whose enthalpies of transfer and vaporization enthalpies correlate with standards characterized by dipole moments < 3.0 D. Bottom row: $N$-methylimidazole (7), pyridazine (8), 4- $N, N$-dimethylaminopyridine (9), imidazo[1,2a]pyridine (10), 1,2,4-triazolo[1,5-a]pyrimidine (11), phthalazine (12) and benzo[c] cinnoline (13); a series of heterocycles whose enthalpies of transfer and vaporization enthalpies correlate with standards characterized by dipole moments $>3.0 \mathrm{D}$.<smiles>NNc1ncnc2ccccc12</smiles>

14<smiles>Cc1nc2ccccn2c1C(=O)NCc1ccccc1</smiles>

15<smiles>Oc1cccc(-c2nc(N3CCOCC3)c3sccc3n2)c1</smiles>

16<smiles>Cc1cn2cc(-c3cccc(O)c3)nc(N3CCOCC3)c2n1</smiles>

17
Figure 2. Structures of 1-hydrazinylphthalazine (14), an imidazo[1,2a] pyridine-3-carboxamide (15) and an example of two classes of PI3K inhibitors $(16,17)$.

popular pharmacophores. 1-Hydrazinylphthalazine (14) used to treat hypertension is on the World Health Organizations List of Essential Medicines, ${ }^{4}$ Figure 2. 1,2,4-Triazolo[1,5-a]pyrimidine (11) and imidazo[1,2-a]pyridine (10) derivatives are reported to be physiologically active possessing a broad spectrum of activity including anticancer and antiviral properties. ${ }^{5,6}$ Imidazo$[1,2-a]$ pyridine-3-carboxamides, compound 15 and derivatives for example, appear to be a new class of potent selective antituberculosis agents. ${ }^{7,8}$ BKM-120 (16, Figure 2), currently under evaluation in human clinical trials as a phosphoinositide3-kinase (PI3K) inhibitor, has a similar 4N,N-dialkylaminopyridinyl scaffold as found in 4-N,N-dimethylaminopyridine (9). ${ }^{9}$ The enzyme, PI3K, which exists in several isoforms, plays an important role in cancer cell growth, survival, angiogenesis and metathesis. $^{9-12}$ Compounds $\mathbf{1 6}$ and $\mathbf{1 7}$ in Figure 2 illustrate examples of two classes of a series of novel imidazo[1,2-a]pyrazine
PI3K inhibitors reported recently. ${ }^{12}$ These and other observations raise the following question: Do the energetics associated with an enhanced polarity of the parent scaffold play any role in the efficacy of enzyme inhibition if other important factors such as stereochemistry, lipophilicity, and hydrogen bonding are taken into account?

The structure of the materials with dipoles $>3 \mathrm{D}$ share several common physical properties. They are all polar, planar, and exhibit extensive conjugation. Benzo[c]cinnoline (13, Figure 1) for example, has been reported to form dimers in solution, presumably as a result of the large dipole moment. ${ }^{13}$ The solid state structure of benzo[c]cinnoline can be considered an assembly of isolated coplanar pairs of molecules $3.473 \AA$ Apart. ${ }^{14}$ This solid state structure has been suggested as a model for the dimer in solution. 1,2,4-Triazolo[1,5-a]pyrimidine, also very polar, packs in columns, with the center of each coplanar molecule slightly offset from each other $3.253 \AA$ apart. ${ }^{1}$

The solid state structure of phthalazine, the only other crystalline member of this group to be identified is currently unknown.

Imidazo $[1,2-a]$ pyrazine, Figure 3, combines pyrazine (1), found to correlate with compounds exhibiting dipole moments $<3.0 \mathrm{D}$,<smiles>c1cn2ccnc2cn1</smiles>

Figure 3. Structure of imidazo $[1,2-a]$ pyrazine.

the top row of Figure 1, with an $\mathrm{N}$-substituted imidazole, a member of the group of molecules with dipoles $>3 \mathrm{D}$. The dipole moment of imidazo[1,2-a]pyrazine is current unknown. This work examines the vaporization enthalpy of imidazo$[1,2-a]$ pyrazine to determine to which set it is a member. Several other thermodynamic properties of this material alone with the solid state structure of both imidazo[1,2-a]pyrazine and phthalazine are also reported to determine if $\pi-\pi$ stacking in the solid state is a characteristic of all polar substances that share the common characteristics described above. Molecular association, 
if persistent in the liquid phase is a possible explanation for the vaporization enthalpy differences observed.

\section{EXPERIMENTAL SECTION}

2.1. Materials. 2.1.1. Materials (St. Louis). The origin and purity of the compounds as reported by the suppliers are reported in Table 1. Commercial imidazo[1,2-a]pyrazine, $97 \%$

Table 1. Origin and Analysis ${ }^{a}$ of the Heterocycles

\begin{tabular}{|c|c|c|c|}
\hline & compound & supplier & $\begin{array}{l}\text { purity, mass } \\
\text { fraction }\end{array}$ \\
\hline $\mathrm{C}_{4} \mathrm{H}_{4} \mathrm{~N}_{2}$ & pyridazine & Sigma-Aldrich & 0.98 \\
\hline $\mathrm{C}_{5} \mathrm{H}_{6} \mathrm{~N}_{2}$ & 3-methylpyridazine & Sigma-Aldrich & 0.99 \\
\hline $\mathrm{C}_{5} \mathrm{H}_{6} \mathrm{~N}_{2}$ & 4-methylpyrimidine & Sigma-Aldrich & 0.97 \\
\hline $\mathrm{C}_{6} \mathrm{H}_{5} \mathrm{~N}_{3}$ & imidazo $[1,2$-a $]$ pyrazine & Sigma-Aldrich & $0.97^{c}$ \\
\hline $\mathrm{C}_{7} \mathrm{H}_{6} \mathrm{~N}_{2}$ & imidazo $[1,2-a]$ pyridine & Sigma-Aldrich & 0.99 \\
\hline $\mathrm{C}_{7} \mathrm{H}_{9} \mathrm{~N}$ & 3,5-lutidine & Akcros & 0.97 \\
\hline $\mathrm{C}_{7} \mathrm{H}_{12} \mathrm{~N}_{2}$ & $\begin{array}{l}\text { 1,5-diazabicyclo }[4.3 .0] \text { non- } \\
\text { 5-ene }\end{array}$ & Sigma-Aldrich & 0.98 \\
\hline $\mathrm{C}_{8} \mathrm{H}_{6} \mathrm{~N}_{2}$ & phthalazine & Sigma-Aldrich & 0.98 \\
\hline $\mathrm{C}_{9} \mathrm{H}_{7} \mathrm{~N}$ & quinoline & Sigma-Aldrich & 0.96 \\
\hline $\mathrm{C}_{10} \mathrm{H}_{8} \mathrm{~N}_{2}$ & 4-phenylpyrimidine & Sigma-Aldrich & 0.96 \\
\hline
\end{tabular}

${ }^{a}$ Mass fraction. ${ }^{b}$ Chemical purity as supplied. See section 2.3.2 for a discussion of additional purification and the effects of chemical purity on these experiments. ${ }^{c}$ Sample purity of imidazo[1,2-a]pyrazine is discussed in sections 2.1.1, 2.1.2, and 2.2.

(St. Louis) was dissolved, filtered, and recrystallized from ethyl acetate-hexane before use and analyzed by gas chromatography. A sample was also sublimed under reduced pressure and the sublimed sample recrystallized from heptane. Analysis following recrystallization or sublimation indicated a mass fraction $>0.99$ as measured by gas chromatography using an FID detector. The crystal structure of phthalazine was performed on the commercial sample.

2.1.2. Materials (Rostock). The degree of purity of the material purchased from Aldrich was determined using a GC on an HP-5 capillary column, column length of $30 \mathrm{~m}, 0.32 \mathrm{~mm}$ ID, and film thickness of $0.25 \mu \mathrm{m}$. No impurities (greater than 0.02 mass percent) could be detected by GC in the imidazo$[1,2-a]$ pyrazine sample used for the vapor pressure measurements using the transpiration method.

2.2. Preconditioning of the imidazo[1, 2-a]pyrazine sample (Rostock). The IR spectrum of commercial imidazo$[1,2-a]$ pyrazine shows a broad $\mathrm{OH}$ band specific for hydrate formation that is absent in the anhydrous form. In order to remove water from the sample, a careful preconditioning of the sample was performed inside of the saturator prior to the transpiration experiments. After filling of the U-shaped saturator with the sample (as received of commercial origin), the carrier gas with the flow rate of $1 \mathrm{dm}^{3} \cdot \mathrm{h}^{-1}$ was passed through the system at the temperature slightly above the melting point. From our experience, any volatile impurities are easily removed during such a preconditioning within few hours. Monitoring of purification is performed by GC analysis of the sample withdrawn from the cooling trap. The flame-ionization detector of the GC is not sensitive for water. In order to prove absence of water traces in the sample, numerous probes were taken consequently in the course of the sample flushing. After the amount of compound collected in the cold trap (determined by GC analysis with an internal standard) within a specific length of time became constant, the sample was considered to be ready for vapor pressure measurements.
2.3. Vapor Pressure and Vaporization Enthalpies. 2.31. Vapor Pressure and Vaporization Enthalpies by Transpiration. Absolute vapor pressures and vaporization enthalpy of imidazo[1,2-a]pyrazine over the liquid sample were determined by the transpiration method as previously described. ${ }^{15,16}$ About $0.5 \mathrm{~g}$ of the sample was mixed with small glass beads and placed in a thermostated U-shaped saturator. A well-defined nitrogen stream was passed through the saturator at a constant temperature $( \pm 0.1 \mathrm{~K})$, and the transported material was collected in a cold trap. The amount of condensed sample of imidazo[1,2-a]pyrazine was determined by GC analysis using an external standard $n-\mathrm{C}_{13} \mathrm{H}_{28}$. The absolute vapor pressure $p_{i}$ at each temperature $T_{i}$ was calculated from the amount of the product collected within a definite period. Assuming validity of the Dalton's law applied to the nitrogen stream saturated with the substance $i$, values of $p_{\mathrm{i}}$ were calculated with the following equations:

$$
p_{i}=\frac{m_{\mathrm{i}} \cdot R \cdot T_{\mathrm{a}}}{V \cdot M_{\mathrm{i}}} \quad V=V_{\mathrm{N}_{2}}+V_{i} \quad\left(V_{\mathrm{N}_{2}} \gg V_{i}\right)
$$

where $R=8.314462 \mathrm{~J} \cdot \mathrm{K}^{-1} \cdot \mathrm{mol}^{-1}, m_{i}$ is the mass of the transported compound, $M_{\mathrm{i}}$ is the molar mass of the compound, and $V_{i}$ is its volume contribution to the gaseous phase. $V_{\mathrm{N}_{2}}$ is the volume of the carrier gas and $T_{\mathrm{a}}$ is the temperature of the soap bubble meter used for measurement of the gas flow. The volume of the carrier gas $V_{\mathrm{N}_{2}}$ was determined from the flow rate and the time measurement. Accuracy of vapor pressures measured by transpiration method governed mostly by the reproducibility of the GC analysis as well as by the volume $V_{\mathrm{N}_{2}}$ determination. ${ }^{16}$ The standard uncertainties $(u)$ of the measured vapor pressures have been calculated tobe $u(p / \mathrm{Pa})=0.025+0.025(p / \mathrm{Pa})$ for $p>5$ to $1000 \mathrm{~Pa}$. Vapor pressures of naphthalene, series of $n$-alkanols, series of aliphatic esters, where reliable data at $p=$ (0.1 to 1000) Pa from different methods were available. Vapor pressures of naphthalene, series of $n$-alkanols, series of aliphatic esters derived from the transpiration method in the range from 0.1 to $1000 \mathrm{~Pa}$ were comparable with available high-precision data within (1 to 3 ) \%. ${ }^{15,16}$

Temperature dependence of vapor pressures $p_{i}$ measured for imidazo $[1,2-a]$ pyrazine was fit with the following equation: ${ }^{15}$

$$
R \cdot \ln p_{i}=a+\frac{b}{T}+\Delta_{\mathrm{l}}^{\mathrm{g}} C_{\mathrm{p}, \mathrm{m}}^{0} \cdot \ln \left(\frac{T}{T_{0}}\right)
$$

where $a$ and $b$ are adjustable parameters and $\Delta_{\mathrm{P}}^{\mathrm{g}} C_{\mathrm{p}, \mathrm{m}}^{0}$ is the difference of the molar heat capacities of the gaseous and the liquid phase, respectively. $T_{0}$, appearing in eq 2 , is an arbitrarily chosen reference temperature, where $T_{0}=298.15 \mathrm{~K}$ in this case, and $R$ is the molar gas constant, $8.3145 \mathrm{~J} \cdot \mathrm{K}^{-1} \cdot \mathrm{mol}^{-1}$.

The vaporization enthalpy at temperature $T$ was derived from the temperature dependence of vapor pressures using eq 3

$$
\Delta_{\mathrm{l}}^{\mathrm{g}} H_{\mathrm{m}}^{0}(T)=-b+\Delta_{\mathrm{l}}^{\mathrm{g}} C_{\mathrm{p}, \mathrm{m}}^{0} \cdot T
$$

The value of $\Delta_{\mathrm{\rho}}^{\mathrm{g}} C_{\mathrm{p}, \mathrm{m}}^{0}=-(72.5 \pm 16) \mathrm{J} \cdot \mathrm{K}^{-1} \cdot \mathrm{mol}^{-1}$ has been calculated according to the procedure developed by Chickos et al. ${ }^{17}$ based on the isobaric molar heat capacity $C_{\mathrm{p}, \mathrm{m}}^{0}(1,298.15 \mathrm{~K})=$ (194.3) $\mathrm{J} \cdot \mathrm{K}^{-1} \cdot \mathrm{mol}^{-1}$ calculated by the group contribution method. $^{18,19}$

Vaporization entropy at temperature $T$ were also derived from the temperature dependence of vapor pressures using eq 4

$$
\Delta_{\mathrm{l}}^{\mathrm{g}} S_{\mathrm{m}}^{0}(T)=\Delta_{\mathrm{l}}^{\mathrm{g}} H_{\mathrm{m}}^{0} / T+R \ln \left(p_{i} / p^{0}\right)
$$


Experimental absolute vapor pressures measured by the transpiration method, coefficients $a$ and $b$ of eq 2 , as well as values of $\Delta_{\mathrm{P}}^{\mathrm{g}} H_{\mathrm{m}}(T)$ and $\Delta_{\mathrm{P}}^{\mathrm{g}} S_{m}^{0}(T)$ are provided below. The procedure for calculation of the combined uncertainties of the vaporization enthalpy was described elsewhere. ${ }^{16}$ It includes uncertainties from the transpiration experimental conditions, uncertainties in vapor pressure, and uncertainties in the temperature adjustment to $T=298.15 \mathrm{~K}$.

2.32. Vapor Pressure and Vaporization Enthalpies by Correlation Gas Chromatography. Chemical purity is not of major concern in correlation gas chromatography experiments since the chromatography generally separates the various components. The measurements themselves are performed with mixtures and provided any impurities are present in minimal amount, they have little or no effect on retention times as determined experimentally. Additionally, we have found that even if two materials have identical retention times, this does not seem to affect the thermodynamic properties evaluated. ${ }^{20}$ The experiments in St. Louis were performed on an HP 5890 gas chromatograph running HP Chemstation. The column used for all but one analysis was a $15 \mathrm{~m}$ Supelco SPB-5 capillary column, $(0.32 \mathrm{~mm}$ i.d., $1 \mu \mathrm{m}$ film thickness) at a split ratio of approximately 100/1. Chromatographs were obtained at $T=5 \mathrm{~K}$ increments over a $T=30 \mathrm{~K}$ range. Run 1 was run on an $30 \mathrm{~m}$ SPB5 column. Temperature was controlled by the instrument and monitored by a Fluke digital thermometer. The solvent used was methanol which also served the non-retained reference at the temperature of these experiments. Helium was used as the carrier gas. The standards and target were injected simultaneously. Retention times are provided in the Supporting Information (Tables S1A-S5A).

The adjusted retention time, calculated as the difference between an analyte's retention time and that of the unretained reference, measures the retention time on the column and is inversely proportional to its vapor pressure off the column. ${ }^{21}$ A plot of $\ln \left(t_{0} / t_{\mathrm{a}}\right)$ versus $1 / T$, where $t_{\mathrm{a}}$ represents the adjusted retention time and $t_{0}$ is the reference time $60 \mathrm{~s}$, results in a straight line with a slope equal to $-\Delta_{\mathrm{trn}} H_{\mathrm{m}}\left(T_{\mathrm{m}}\right) / R$. The term $\Delta_{\mathrm{trn}} H_{\mathrm{m}}\left(T_{\mathrm{m}}\right)$ refers to the molar enthalpy of transfer from the stationary phase of the column to the gas phase at the mean temperature of measurement, $T_{\mathrm{m}}$, and $R$ is the gas constant.

The enthalpy of transfer is related to the vaporization enthalpy by eq 5 , where $\Delta_{\text {intr }} H_{\mathrm{m}}\left(T_{\mathrm{m}}\right)$ represents the enthalpy of interaction of the analyte with the column. ${ }^{21}$ Provided the standards are appropriately chosen, a second plot of $\Delta_{\mathrm{P}}^{\mathrm{g}} H_{\mathrm{m}}(298.15 \mathrm{~K})$ of the standards against their corresponding $\Delta_{\mathrm{trm}} H_{\mathrm{m}}\left(T_{\mathrm{m}}\right)$ values is also linear. The equation of this line together with the value of
$\Delta_{\mathrm{trn}} H_{\mathrm{m}}\left(T_{\mathrm{m}}\right)$ of the target provides the $\Delta_{\mathrm{P}}^{\mathrm{g}} H_{\mathrm{m}}(298.15 \mathrm{~K})$ value of the target. Heat capacity adjustments of $\Delta_{\mathrm{P}}^{\mathrm{g}} H_{\mathrm{m}}\left(T_{\mathrm{m}}\right)$ to $T=$ $298.15 \mathrm{~K}$ are approximated by the $\Delta_{\mathrm{P}}^{\mathrm{g}} H_{\mathrm{m}}(298.15 \mathrm{~K})$ values of the standards

$$
\Delta_{\text {trn }} H_{\mathrm{m}}\left(T_{\mathrm{m}}\right)=\Delta_{\mathrm{l}}^{\mathrm{g}} H_{\mathrm{m}}\left(T_{\mathrm{m}}\right)+\Delta_{\text {intr }} H_{\mathrm{m}}\left(T_{\mathrm{m}}\right)
$$

2.4. Fusion Enthalpy. The fusion enthalpy of imidazo[1,2a]pyrazine was measured on a PerkinElmer DSC-7 using the software provided by the manufacturer (Pyris Series Thermal Analysis) under a flow of nitrogen at a scan rate of $5 \mathrm{~K} \mathrm{~min}^{-1}$. The instrument was calibrated using indium as a standard, $w=0.99999\left(\Delta_{\mathrm{cr}}^{1} H=28.6 \mathrm{~J} \cdot \mathrm{g}^{-1} ; T_{\text {fus }} / \mathrm{K}=429.8\right)$, which was provided by the instrument's manufacturer. The calibration was checked using Gold label scintillation grade naphthalene, $w>0.99\left(T_{\text {fus }} / \mathrm{K}=353.7 ; \Delta_{\text {cr }}^{1} H_{\mathrm{m}}\left(T_{\text {fus }}\right)=19.07 \mathrm{~kJ} \cdot \mathrm{mol}^{-1}\right.$; literature $\left.^{22}=353.4 \mathrm{~K} ; 19.06 \mathrm{~kJ} \cdot \mathrm{mol}^{-1}\right)$. Details are discussed below.

2.5. X-ray Diffraction. The diffraction data sets were collected on a Bruker Kappa Apex II Charge Coupled Device (CCD) Detector system single crystal X-ray diffractometer equipped with an Oxford Cryostream LT device. The SHELXTLPLUS software package was used to solve the structure. Additional details are discussed below and provided in the Supporting Information

2.6. Infrared Spectroscopy. Infrared spectra of the title compound were run on an Thermo Nicolet 360 FT IR instrument equipped with an ATR accessory. Spectra of both the recrystallized and sublimed samples were run. The commercial sample contain a broad $\mathrm{O}-\mathrm{H}$ peak at approximately $3200 \mathrm{~cm}^{-1}$, which was absent in the sublimed material. Otherwise the two spectra were very similar.

2.7. Temperature Adjustments. All vaporization enthalpies used in this work are available at $T=298.15 \mathrm{~K}$ having been adjusted for temperature previously by either the authors or others. ${ }^{1,2,23-27}$ The fusion enthalpy of imidazo[1,2-a]pyrazine described below was adjusted to $T=298.15 \mathrm{~K}$ using eq $6{ }^{19}$ The heat capacity of both the solid and liquid phases $\left(\left(C_{\mathrm{p}}(\mathrm{cr})\right.\right.$ and $C_{\mathrm{p}}(1)$, respectively) of the anhydrous form was calculated using group addititvity. ${ }^{18}$ The commercial sample and the sample obtained by recrystallization was a hydrate and contained a molecule of water as described below. The heat capacity of this material was estimated as the sum of the heat capacity of imidazo[1,2a]pyrazine $+1 \mathrm{~mol}$ of $\mathrm{H}_{2} \mathrm{O} ;\left(C_{\mathrm{p}}(1)_{\mathrm{H}_{2} \mathrm{O}}=\right.$ $\left.75.3 \mathrm{~J} \cdot \mathrm{mol}^{-1} \cdot \mathrm{K}^{-1} ; C_{\mathrm{p}}(\mathrm{cr})_{\mathrm{H}_{2} \mathrm{O}}=34.4 \mathrm{~J} \cdot \mathrm{mol}^{-1} \cdot \mathrm{K}^{-1}\right)$. A one-to-one stoichiometry is suggested by the crystal structure

$$
\left.\frac{\Delta_{\mathrm{cr}}{ }^{1} H(298.15 \mathrm{~K})}{\left(\mathrm{kJ} \cdot \mathrm{mol}^{-1}\right)}=\frac{\Delta_{\mathrm{cr}}{ }^{1} H\left(T_{\mathrm{fus}}\right)}{\left(\mathrm{kJ} \cdot \mathrm{mol}^{-1}\right)}+\left(\left[\frac{\left(0.15 \cdot C_{\mathrm{p}}(\mathrm{cr})-0.26 \cdot C_{\mathrm{p}}(\mathrm{l})\right)}{\left(\mathrm{J} \cdot \mathrm{mol}^{-1} \cdot \mathrm{K}^{-1}\right)}-9.83\right)\right]\left[\left(\frac{T_{\mathrm{fus}}}{\mathrm{K}}\right)-298.15\right]\right) / 1000
$$

2.8. Uncertainties. The slopes and intercepts reported below were calculated by linear regression. Uncertainties associated with results derived by combination of two or more experimental values were derived as $\left(u_{1}^{2}+u_{2}^{2}+\ldots\right)^{0.5}$. All uncertainties refer to one standard deviation. One standard deviation associated with adjustment of the fusion enthalpy to $T=298.15 \mathrm{~K}$ is estimated as $30 \%$ of the total temperature adjustment. The crystallographic refinement program uses "standard uncertainties", representing $68 \%$ probability.

2.9. Standards. Two sets of standards were used for the correlation gas chromatography experiments. These are segregated in Table 2 according to their dipole moments. The first group represents compounds characterized by dipole moments less than 3.0, ${ }^{1,25-27}$ whereas the dipole moments in the second group exceed 3.0 D. ${ }^{1,2,23,24}$ Two sets of experiments were conducted, duplicate runs with both sets of standards.

\section{RESULTS}

3.1. Vaporization Enthalpies. Runs 1 and 2 of Table 3 represent correlations with heterocyclic members associated with dipole moments $<3.0 \mathrm{D}$ and runs $3-5$ of Table 4 correspond to correlations with substances exhibiting values $>3.0 \mathrm{D}$. 
Table 2. Vaporization Enthalpies of the Standards

\begin{tabular}{|c|c|c|}
\hline dipole moment $<3.0 \mathrm{D}$ & $\Delta_{\mathrm{P}}^{\mathrm{g}} H_{\mathrm{m}}(298 \mathrm{~K})$ (literature) & ref \\
\hline \multicolumn{3}{|c|}{$\mathrm{kJ} \cdot \mathrm{mol}^{-1}$} \\
\hline 4-methylpyrimidine & $44.2 \pm 2.5$ & 25 \\
\hline 3,5-lutidine & $49.32 \pm 0.17$ & 26 \\
\hline quinoline & $59.31 \pm 0.2$ & 27 \\
\hline 1,5-diazabicyclo[4.3.0]non-5-ene & $61.88 \pm 0.21$ & 1 \\
\hline 4-phenylpyrimidine & $68.8 \pm 2.5$ & 25 \\
\hline \multirow[t]{2}{*}{ dipole moment $>3.0 \mathrm{D}$} & $\Delta_{\mathrm{\rho}}^{\mathrm{g}} H_{\mathrm{m}}(298 \mathrm{~K})$ (literature) & ref \\
\hline & \multicolumn{2}{|l|}{$\mathrm{kJ} \cdot \mathrm{mol}^{-1}$} \\
\hline pyridazine & $54.6 \pm 0.2,53.5 \pm 0.4$ & 2,24 \\
\hline 3-methylpyridazine & $56.1 \pm 4.4$ & 23 \\
\hline imidazo $[1,2$-a $]$ pyridine & $67.41 \pm 0.23$ & 1 \\
\hline phthalazine & $72.8 \pm 5.6$ & 23 \\
\hline
\end{tabular}

The equations listed below each respective table define the properties of the correlations and the associated correlation coefficients provide a measure of the linearity of the correlations. Results of all five correlations are summarized in Table 5. Two sets of averages are listed in Table $5,(62.0 \pm 2.6) \mathrm{kJ} \cdot \mathrm{mol}^{-1}$ obtained using standards with dipole moments $<3.0 \mathrm{D}$ and $(67.9 \pm 1.4) \mathrm{kJ} \cdot \mathrm{mol}^{-1}$ using standards with dipole moments > $3.0 \mathrm{D}$. The values in column 5 for runs $3-5$ were generated using the most recent value for pyridazine. ${ }^{2}$ 4-Methylpyridazine was also treated as an unknown. Both sets of vaporization enthalpy results for 4-methylpyridazine remain within experimental error each other.

In addition to the vaporization enthalpies measured by correlation, the vaporization enthalpy of imidazo[1,2-a]pyrazine was also measured by transpiration. These measurements are summarized in Table 6. A vaporization enthalpy of $(70.7 \pm 1.0)$ $\mathrm{kJ} \cdot \mathrm{mol}^{-1}$ measured by transpiration, eq 7 , compares quite favorably with $(67.9 \pm 1.4) \mathrm{kJ} \cdot \mathrm{mol}^{-1}$ obtained by correlation and suggests that the value of $(62.0 \pm 2.6) \mathrm{kJ} \cdot \mathrm{mol}^{-1}$ is incorrect.

$$
\begin{gathered}
\text { Imidazo }[1,2 \text {-a }] \text { pyrazine; } \Delta_{1}^{\mathrm{g}} H_{\mathrm{m}}(298.15 \mathrm{~K})=(70.7 \pm 1.0) \mathrm{kJ} \cdot \mathrm{mol}^{-1} \\
R \cdot \ln \left(p / p_{o}\right)=307.65-92341.6 /(T / \mathrm{K}) \\
-72.5 \cdot \ln [(T / \mathrm{K}) / 298.15]
\end{gathered}
$$

These results support the notion that the imidazo[1,2-a]pyrazine core is a member of the more polar group and presumable is characterized by a dipole moment $>3.0 \mathrm{D}$. Using the average value of both results, $(69.3 \pm 1.2) \mathrm{kJ} \cdot \mathrm{mol}^{-1}$, comparison with the average of runs 1 and 2 results in a difference of $(7.3 \pm 1.2) \mathrm{kJ} \cdot \mathrm{mol}^{-1}$, in very good agreement with differences of $(6.9 \pm 0.3) \mathrm{kJ} \cdot \mathrm{mol}^{-1}$ observed previously for the other compounds in this class.

3.2. Fusion Enthalpy. The DSC curve for the commercial sample of imidazo[1,2-a]pyrazine recrystallized from ethyl acetate is shown as the upper curve in Figure 4. Following the structural analysis described below, which indicated the presence of a hydrate, the sample was sublimed and this resulted in a sample that exhibited the lower curve in Figure 4. The small peak observed at $T=(334.1 \pm 0.1) \mathrm{K}$ compares to a fusion temperature of $T_{\text {fus }}=(336.3 \pm 0.1) \mathrm{K}$ for the hydrate and is most likely due to the presence of a small amount of hydrate. Accordingly, using the fusion data in Table 7A for the hydrated form, the enthalpy associated with transition at $T=$ $(334.1 \pm 0.1) \mathrm{K}$ amounts to a total of $3.7 \%$ hydrate present in the anhydrous form as evaluated by DSC. Adjusting the fusion enthalpy of $(14.7 \pm 1.2) \mathrm{kJ} \cdot \mathrm{mol}^{-1}$ for its presence, results in a fusion enthalpy of $(15.3 \pm 1.3) \mathrm{kJ} \cdot \mathrm{mol}^{-1}$ for the anhydrous form which melts at $T_{\text {fus }}=(359.2 \pm 0.6) \mathrm{K}$. This is summarized in Table $7 \mathrm{~B}$. The hydrated form melts at a lower temperature but exhibits a larger fusion enthalpy, $(19.6 \pm 0.6) \mathrm{kJ} \cdot \mathrm{mol}^{-1}$. The fusion enthalpy of the anhydrous form at $T=298.15 \mathrm{~K}$ is estimated as $(12.8 \pm 1.5) \mathrm{kJ} \cdot \mathrm{mol}^{-1}$. The temperature adjustment is summarized in the last row of Table 7B.

3.3. Sublimation Enthalpy. The sublimation enthalpy of imidazo[1,2-a]pyrazine can be calculated as the sum of its vaporization and fusion enthalpy, $(69.3 \pm 1.2)+(12.75 \pm 1.5) \mathrm{kJ} \cdot \mathrm{mol}^{-1}$. A value of at $(82.1 \pm 1.9) \mathrm{kJ} \cdot \mathrm{mol}^{-1}$ is calculated at $T=298.15 \mathrm{~K}$.

3.4. Crystal Structures. Extensive conjugation, planarity and polarity are common properties exhibited by two of the crystalline members that exhibit enhanced vaporization enthalpies. ${ }^{1}$ In an effort to determine whether imidazo[1,2-a]pyrazine and phthalazine pack in a manner similar to benzo$[\mathrm{c}]$ cinnnoline ${ }^{14}$ and 1,2,4-triazolo[1,5-a] pyrimidine, ${ }^{1}$ the crystal structures of both were determined. All other current members

\begin{tabular}{|c|c|c|c|c|c|}
\hline \multirow[b]{2}{*}{ run 1} & \multirow{2}{*}{$\frac{\text { slope, } T}{\mathrm{~K}}$} & \multirow[t]{2}{*}{ intercept } & \multirow{2}{*}{$\frac{\Delta H_{\mathrm{trn}}(424 \mathrm{~K})}{\mathrm{kJ} \cdot \mathrm{mol}^{-1}}$} & \multirow{2}{*}{$\frac{\Delta_{\mathrm{P}}^{\mathrm{g}} H_{\mathrm{m}}(298 \mathrm{~K})(\text { literature })}{\mathrm{kJ} \cdot \mathrm{mol}^{-1}}$} & \multirow{2}{*}{$\frac{\Delta_{\mathrm{P}}^{\mathrm{g}} H_{\mathrm{m}}(298 \mathrm{~K})(\mathrm{calcd})}{\mathrm{kJ} \cdot \mathrm{mol}^{-1}}$} \\
\hline & & & & & \\
\hline 4-methylpyrimidine & -3498.1 & 9.647 & 29.08 & $44.2 \pm 2.4$ & $44.1 \pm 1.1$ \\
\hline 3,5-lutidine & -4033.8 & 10.162 & 33.54 & $49.32 \pm 0.17$ & $49.7 \pm 1.1$ \\
\hline quinoline & -4907.8 & 10.866 & 40.80 & $59.31 \pm 0.2$ & $58.9 \pm 1.2$ \\
\hline 1,5-diazabicyclo[4.3.0]non-5-ene & -5194.0 & 11.516 & 43.18 & $61.88 \pm 0.21$ & $61.9 \pm 1.3$ \\
\hline imidazo[1,2-a]pyrazine & -5185.9 & 11.336 & 43.11 & & $61.8 \pm 1.3$ \\
\hline \multirow[t]{2}{*}{ 4-phenylpyrimidine } & -5857.1 & 12.089 & 48.69 & $68.8 \pm 2.5$ & $68.9 \pm 1.4$ \\
\hline & slope, $T$ & intercept & $\Delta H_{\mathrm{trn}}(425 \mathrm{~K})$ & $\Delta_{\mathrm{P}}^{\mathrm{g}} H_{\mathrm{m}}(298 \mathrm{~K})$ (literature) & $\Delta_{\mathrm{P}}^{\mathrm{s}} H_{\mathrm{m}}(298 \mathrm{~K})(\mathrm{calcd})$ \\
\hline run 2 & $\mathrm{~K}$ & & $\mathrm{~kJ} \cdot \mathrm{mol}^{-1}$ & $\mathrm{~kJ} \cdot \mathrm{mol}^{-1}$ & $\mathrm{~kJ} \cdot \mathrm{mol}^{-1}$ \\
\hline 4-methylpyrimidine & -3411.8 & 9.507 & 28.36 & $44.2 \pm 2.4$ & $44.2 \pm 3.4$ \\
\hline 3,5-lutidine & -3990.2 & 10.129 & 33.17 & $49.32 \pm 0.17$ & $50.2 \pm 3.6$ \\
\hline quinoline & -4813.4 & 10.707 & 40.02 & $59.31 \pm 0.2$ & $58.8 \pm 4.0$ \\
\hline 1,5-diazabicyclo[4.3.0]non-5-ene & -4976.1 & 11.082 & 41.37 & $61.88 \pm 0.21$ & $60.5 \pm 4.0$ \\
\hline imidazo $[1,2-\mathrm{a}]$ pyrazine & -5126.5 & 11.27 & 42.62 & & $62.1 \pm 4.1$ \\
\hline 4-phenylpyrimidine & -5854.7 & 12.157 & 48.67 & $68.8 \pm 2.5$ & $69.7 \pm 4.4$ \\
\hline
\end{tabular}
of this group are liquids at $T=298.15 \mathrm{~K}$.

Table 3. Correlation of $\Delta_{\mathrm{l}}^{\mathrm{g}} H_{\mathrm{m}}(298 \mathrm{~K})$ with $\Delta H_{\mathrm{trn}}\left(T_{\mathrm{m}}\right)$ for Runs 1 and $2^{a}$

Run 1: $\Delta_{\mathrm{P}}^{\mathrm{g}} H_{\mathrm{m}}(298.15 \mathrm{~K}) / \mathrm{kJ} \cdot \mathrm{mol}^{-1}=(1.27 \pm 0.02) \Delta H_{\mathrm{trn}}(424 \mathrm{~K})+(7.18 \pm 0.9) ; r^{2}=0.9991$

Run 2: $\Delta_{\mathrm{P}}^{\mathrm{g}} H_{\mathrm{m}}(298.15 \mathrm{~K}) / \mathrm{kJ} \cdot \mathrm{mol}^{-1}=(1.26 \pm 0.07) \Delta H_{\mathrm{trn}}(425 \mathrm{~K})+(8.54 \pm 2.8) ; r^{2}=0.9905$

${ }^{a}$ Uncertainties are one standard deviation; $p / \mathrm{Pa}=101325$. 
Table 4. Correlation of $\Delta_{\mathrm{l}}^{\mathrm{g}} H_{\mathrm{m}}(298 \mathrm{~K})$ with $\Delta H_{\operatorname{trn}}\left(T_{\mathrm{m}}\right)$ for Runs 3, 4, and $5^{a}$

\begin{tabular}{|c|c|c|c|c|c|}
\hline \multirow[b]{2}{*}{ run 3} & slope, $T$ & intercept & $\Delta H_{\text {trn }}(424 \mathrm{~K})$ & $\Delta_{\mathrm{P}}^{\mathrm{g}} H_{\mathrm{m}}(298 \mathrm{~K})$ (literature) & $\Delta_{\mathrm{P}}^{\mathrm{g}} H_{\mathrm{m}}(298 \mathrm{~K})($ calcd $)$ \\
\hline & \multicolumn{2}{|l|}{$\mathrm{K}$} & $\mathrm{kJ} \cdot \mathrm{mol}^{-1}$ & $\mathrm{~kJ} \cdot \mathrm{mol}^{-1}$ & $\mathrm{~kJ} \cdot \mathrm{mol}^{-1}$ \\
\hline pyridazine & -3707.5 & 9.382 & 30.82 & \multirow[t]{2}{*}{$54.62 \pm 0.22$} & $54.7 \pm 1.7$ \\
\hline 3-methylpyridazine & -4051.8 & 9.794 & 33.69 & & $57.8 \pm 1.8$ \\
\hline imidazo $[1,2$-a $]$ pyridine & -5100.2 & 10.868 & 42.40 & \multirow[t]{2}{*}{$67.41 \pm 0.23$} & $67.1 \pm 2.0$ \\
\hline imidazo $[1,2-a]$ pyrazine & -5185.0 & 10.987 & 43.11 & & $67.8 \pm 2.0$ \\
\hline \multirow[t]{2}{*}{ phthalazine } & -5769.8 & 11.433 & 47.97 & $72.8 \pm 5.6$ & $73.0 \pm 2.1$ \\
\hline & slope, $T$ & intercept & $\Delta H_{\mathrm{trn}}(414 \mathrm{~K})$ & $\Delta_{\mathrm{P}}^{\mathrm{g}} H_{\mathrm{m}}(298 \mathrm{~K})$ (literature) & $\Delta_{\mathrm{P}}^{\mathrm{g}} H_{\mathrm{m}}(298 \mathrm{~K})($ calcd $)$ \\
\hline run 4 & $\mathrm{~K}$ & & $\mathrm{~kJ} \cdot \mathrm{mol}^{-1}$ & $\mathrm{~kJ} \cdot \mathrm{mol}^{-1}$ & $\mathrm{~kJ} \cdot \mathrm{mol}^{-1}$ \\
\hline pyridazine & -3492.7 & 9.171 & 29.04 & \multirow[t]{2}{*}{$54.62 \pm 0.22$} & $54.6 \pm 0.9$ \\
\hline 3-methylpyridazine & -3912.6 & 9.795 & 32.53 & & $58.0 \pm 1.0$ \\
\hline imidazo $[1,2$-a $]$ pyridine & -5088.3 & 11.235 & 42.30 & \multirow[t]{2}{*}{$67.41 \pm 0.23$} & $67.6 \pm 1.1$ \\
\hline imidazo $[1,2$-a $]$ pyrazine & -5181.6 & 11.388 & 43.08 & & $68.4 \pm 1.1$ \\
\hline \multirow[t]{2}{*}{ phthalazine } & -5706.1 & 11.735 & 47.44 & $72.8 \pm 5.6$ & $72.7 \pm 1.2$ \\
\hline & slope, $T$ & intercept & $\Delta H_{\text {trn }}(424 \mathrm{~K})$ & $\Delta_{\mathrm{P}}^{\mathrm{g}} H_{\mathrm{m}}(298 \mathrm{~K})$ (literature) & $\Delta_{\mathrm{P}}^{\mathrm{g}} H_{\mathrm{m}}(298 \mathrm{~K})($ calcd $)$ \\
\hline run 5 & $\mathrm{~K}$ & & $\mathrm{~kJ} \cdot \mathrm{mol}^{-1}$ & $\mathrm{~kJ} \cdot \mathrm{mol}^{-1}$ & $\mathrm{~kJ} \cdot \mathrm{mol}^{-1}$ \\
\hline pyridazine & -3842.6 & 10.042 & 31.95 & \multirow[t]{2}{*}{$54.62 \pm 0.22$} & $54.6 \pm 1.0$ \\
\hline 3-methylpyridazine & -4215.2 & 10.529 & 35.04 & & $58.1 \pm 1.0$ \\
\hline imidazo $[1,2$-a $]$ pyridine & -5211.3 & 11.52 & 43.32 & \multirow[t]{2}{*}{$67.41 \pm 0.23$} & $67.6 \pm 1.1$ \\
\hline imidazo[1,2-a]pyrazine & -5216.5 & 11.471 & 43.37 & & $67.6 \pm 1.1$ \\
\hline phthalazine & -5748.4 & 11.843 & 47.79 & \multirow[t]{4}{*}{$72.8 \pm 5.6$} & \multirow[t]{4}{*}{$72.7 \pm 1.2$} \\
\hline \multirow{3}{*}{\multicolumn{4}{|c|}{$\begin{array}{l}\text { Run 3: } \Delta_{\mathrm{P}}^{\mathrm{g}} H_{\mathrm{m}}(298.15 \mathrm{~K}) / \mathrm{kJ} \cdot \mathrm{mol}^{-1}=(1.067 \pm 0.033) \Delta H_{\mathrm{trn}}(424 \mathrm{~K})-(21.8 \pm 1.4) ; r^{2}=0.9990 \\
\text { Run 4: } \Delta_{\mathrm{P}}^{\mathrm{g}} H_{\mathrm{m}}(298.15 \mathrm{~K}) / \mathrm{kJ} \cdot \mathrm{mol}^{-1}=(0.983 \pm 0.02) \Delta H_{\mathrm{trn}}(414 \mathrm{~K})-(26.0 \pm 0.75) ; r^{2}=0.9996 \\
\text { Run 5: } \Delta_{\mathrm{P}}^{\mathrm{g}} H_{\mathrm{m}}(298.15 \mathrm{~K}) / \mathrm{kJ} \cdot \mathrm{mol}^{-1}=(1.14 \pm 0.02) \Delta H_{\mathrm{trn}}(424 \mathrm{~K})-(18.1 \pm 0.8) ; r^{2}=0.9997\end{array}$}} & & \\
\hline & & & & & \\
\hline & & & & & \\
\hline \multicolumn{5}{|c|}{${ }^{a}$ Uncertainties are one standard deviation, $p=101325 \mathrm{~Pa}$} & \\
\hline
\end{tabular}

\section{Table 5. Summary of the Vaporization Enthalpies of Runs 1-5}

\begin{tabular}{|c|c|c|c|c|c|}
\hline & \multicolumn{5}{|c|}{$\Delta_{\mathrm{P}}^{\mathrm{g}} H_{\mathrm{m}}$} \\
\hline & \multicolumn{5}{|c|}{$\mathrm{kJ} \cdot \mathrm{mol}^{-1}$} \\
\hline & & Run 1 & Run 2 & Average $^{a}$ & Literature \\
\hline 4-methylpyrimidine & & $44.1 \pm 1.1$ & $44.2 \pm 3.4$ & $44.2 \pm 2.3$ & $44.2 \pm 2.4$ \\
\hline 3,5-lutidine & & $49.7 \pm 1.1$ & $50.2 \pm 3.6$ & $50.0 \pm 2.4$ & $49.32 \pm 0.17$ \\
\hline quinoline & & $58.9 \pm 1.2$ & $58.8 \pm 4.0$ & $58.9 \pm 2.6$ & $59.31 \pm 0.2$ \\
\hline 1,5-diazabicyclo[4.3.0]non-5-ene & & $61.9 \pm 1.3$ & $60.5 \pm 4.0$ & $61.2 \pm 2.7$ & $61.88 \pm 0.21$ \\
\hline imidazo $[1,2$-a $]$ pyrazine & & $61.8 \pm 1.3$ & $62.1 \pm 4.1$ & $62.0 \pm 2.6$ & \\
\hline \multirow[t]{2}{*}{ 4-phenylpyrimidine } & & $68.9 \pm 1.4$ & $69.7 \pm 4.4$ & $69.4 \pm 2.9$ & $68.8 \pm 2.5$ \\
\hline & Run 3 & Run 4 & Run 5 & Average & literature \\
\hline pyridazine & $54.7 \pm 1.7$ & $54.6 \pm 0.9$ & $54.6 \pm 1.0$ & $54.6 \pm 1.2$ & $54.62 \pm 0.22$ \\
\hline 3-methylpyridazine & $57.8 \pm 1.8$ & $58.0 \pm 1.0$ & $58.1 \pm 1.0$ & $58.0 \pm 1.3$ & $56.1 \pm 4.4$ \\
\hline imidazo[1,2-a]pyridine & $67.1 \pm 2.0$ & $67.6 \pm 1.1$ & $67.6 \pm 1.1$ & $67.4 \pm 1.4$ & $67.41 \pm 0.23$ \\
\hline imidazo[1,2-a]pyrazine & $67.8 \pm 2.0$ & $68.4 \pm 1.1$ & $67.6 \pm 1.1$ & $67.9 \pm 1.4$ & \\
\hline phthalazine & $73.0 \pm 2.1$ & $72.7 \pm 1.2$ & $72.7 \pm 1.2$ & $72.8 \pm 1.5$ & $72.8 \pm 5.6$ \\
\hline
\end{tabular}

3.4.1. Imidazo[1,2-a]pyrazine. The crystal structure of a sample of imidazo[1,2-a]pyrazine from ethyl acetate-hexane corresponding to the upper DSC curve in Figure 4 was found to be disordered. One feature that the structure did reveal was the presence of a stoichiometric amount of water in the crystal. The presence of water was also confirmed as noted above by the infrared spectrum of both the commercial sample as supplied and the one recrystallized. Both samples contained a broad $\mathrm{O}-\mathrm{H}$ stretch at approximately $3300 \mathrm{~cm}^{-1}$. Despite being disordered, the hydrated structure could be solved and refined in both the monoclinic $\left(P 2_{1} / n\right)$ and triclinic space group $P-1$, shown in Figure 5. In both cases the fused ring system and the solvent molecules remain disordered. The root mean square deviation of the overlay of the two disordered molecules $(87: 13 \%)$ in the monoclinic and the 2-unique molecules in the triclinic space groups results in very similar values, which indicates that the two molecules in the asymmetric unit of the triclinic space group are the same. Examination of the extended lattice packing of the hydrated structure shows that the water molecules are not hydrogen bonded in the lattice but are simply filling the crystal voids. Because no improvement in structural parameters were observed by lowering the symmetry, the monoclinic space group was used for this report. Additional details are provided in the Supporting Information Figure S1 and Tables S6-S8.

In an effort to remove the water, a sample recrystallized from ethyl acetate-hexane was also vacuum sublimed and its crystal structure determined. The structure of this material corresponding to the lower DSC curve in Figure 4 is illustrated in Figure 6. Like 1,2,4-triazolo[1,5-a]pyrimidine, the molecule is planar despite the presence of a tricoordinate nitrogen atom. The anhydrous form crystallized in the orthorhombic crystal 
Table 6. Vaporization Enthalpy of Imidazo[1,2-a]pyrazine by Transpiration

\begin{tabular}{|c|c|c|c|c|c|c|c|}
\hline$T^{a}$ & $m^{b}$ & $V\left(\mathrm{~N}_{2}\right)^{c}$ & flow & $p^{d}$ & $u(p)^{e}$ & $\Delta_{1}^{\mathrm{g}} H_{m}^{0}$ & $\Delta_{1}^{\mathrm{g}} S_{m}^{0}$ \\
\hline $\mathrm{K}$ & $\mathrm{mg}$ & $\mathrm{dm}^{3}$ & $\mathrm{dm}^{3} \cdot \mathrm{h}^{-1}$ & $\mathrm{~Pa}$ & $\%$ & $\mathrm{~kJ} \cdot \mathrm{mol}^{-1}$ & $\mathrm{~J} \cdot \mathrm{K}^{-1} \cdot \mathrm{mol}^{-1}$ \\
\hline 369.6 & 9.72 & 1.217 & 1.04 & 164.1 & 4.1 & 65.56 & 124.1 \\
\hline 372.7 & 2.58 & 0.276 & 5.52 & 192.0 & 4.8 & 65.33 & 123.3 \\
\hline 373.8 & 9.49 & 0.956 & 1.04 & 203.8 & 5.1 & 65.25 & 123.1 \\
\hline 377.8 & 3.01 & 0.243 & 1.04 & 253.6 & 6.4 & 64.96 & 122.3 \\
\hline 379.0 & 8.96 & 0.695 & 1.04 & 264.3 & 6.6 & 64.88 & 121.8 \\
\hline 383.0 & 11.53 & 0.695 & 1.04 & 340.0 & 8.5 & 64.59 & 121.4 \\
\hline 385.2 & 9.49 & 0.522 & 1.04 & 373.0 & 9.4 & 64.43 & 120.8 \\
\hline 388.2 & 9.29 & 0.435 & 1.04 & 438.1 & 11.0 & 64.21 & 120.3 \\
\hline 390.2 & 9.66 & 0.400 & 1.04 & 495.2 & 12.4 & 64.06 & 120.1 \\
\hline 393.4 & 12.37 & 0.435 & 1.04 & 583.2 & 14.6 & 63.83 & 119.5 \\
\hline
\end{tabular}

${ }^{a}$ Saturation temperature $(u(T)=0.1 \mathrm{~K}) .{ }^{b}$ Mass of transferred sample condensed at $T=243 \mathrm{~K} .{ }^{c}$ Volume of nitrogen $\left(u(V)=0.005 \mathrm{dm}^{3}\right)$ used to transfer $m(u(m)=0.0001 \mathrm{~g})$ of the sample. ${ }^{d}$ Vapor pressure at temperature $T$, calculated from the $m$ and the residual vapor pressure at $T=243 \mathrm{~K}$. ${ }^{e}$ Uncertainties of experimental vapor pressures were calculated according to the following equation: $u(p / \mathrm{Pa})=0.025+0.025(p /$ $\mathrm{Pa}) p_{0}=1 \mathrm{~Pa}$.

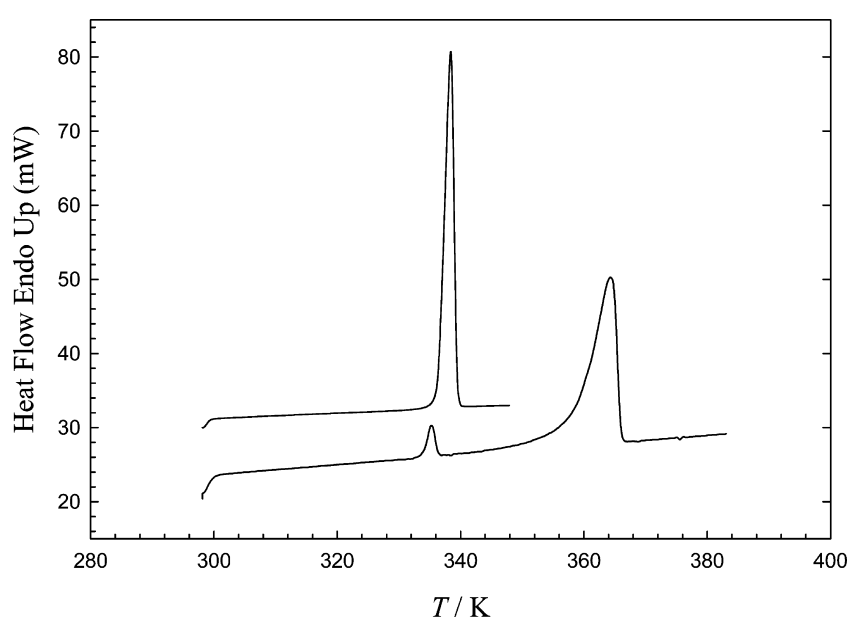

Figure 4. DSC of imidazo $[1,2-a]$ pyrazine hydrate (top) and the anhydrous form containing approximately $3.7 \%$ of the hydrate.

system, space group Pbca. An examination of the packing, Figure 6, indicates that at least in the solid state of this crystalline form, $\pi-\pi$ stacking is not important because no two molecules pack in parallel planes. Additional details of this structure are given in the Supporting Information Figure S2 and Tables S9-S13.

A third sample that was sublimed and then recrystallized from heptane also contained water but was no longer disordered. In this structure, Figure 7, the water molecules are actively involved in the crystal lattice. Although the unit cell shows no evidence of $\pi-\pi$ stacking, extending the packing reveals a coplanar neighboring molecule $3.402 \AA$ apart. In this case, the overlap occurs primarily between the six membered ring of one molecule and a portion of the five-membered ring of a second molecule. The X-ray crystal structure of this form was of relatively poor quality. Additional details for this hydrate are also provided in the Supporting Information Figure S3 and Tables S14-S20.

3.4.2. Phthalazine. Phthalazine is another crystalline heterocycles with a large dipole moment and characterized by an enhanced vaporization enthalpy. This material crystallized in the orthorhombic $\mathrm{Pbca}$ space group. The unit cell is shown in Figure 8 . The solid state structure of phthalazine does show $\pi-\pi$ stacking similar to benzo[c]cinnoline. The structure can be considered an assembly of isolated coplanar pairs of molecules

Table 7A. Fusion Enthalpy of Imidazo $[1,2-a]$ pyrazine $\cdot \mathrm{H}_{2} \mathrm{O}, \Delta_{\mathrm{cr}}^{1} H_{\mathrm{m}}\left(T_{\mathrm{fus}}\right)$, Liquid and Crystalline Heat Capacity, $C_{\mathrm{p}}(1) / C_{\mathrm{p}}(\mathrm{cr})$, and the Temperature Adjustment, $\Delta_{\mathrm{cr}}^{1} C_{\mathrm{p}} \cdot \Delta T^{a}$

\begin{tabular}{|c|c|c|c|c|c|c|}
\hline sample & onset & $\Delta_{\mathrm{cr}}^{1} H_{\mathrm{m}}\left(T_{\text {fus }}\right)$ & $\Delta_{\mathrm{cr}}^{1} H_{\mathrm{m}}\left(T_{\text {fus }}\right)$ & $C_{\mathrm{p}}(1) / C_{\mathrm{p}}(\mathrm{cr})^{b}$ & $\Delta_{\mathrm{cr}}^{1} C_{\mathrm{p}} \cdot \Delta T$ & $\Delta_{\mathrm{cr}}^{1} H_{\mathrm{m}}(298 \mathrm{~K})$ \\
\hline $\mathrm{mg}$ & $\mathrm{K}$ & $\mathrm{J} \cdot \mathrm{g}^{-1}$ & $\mathrm{~kJ} \cdot \mathrm{mol}^{-1}$ & $\mathrm{~J} \cdot \mathrm{mol}^{-1} \cdot \mathrm{K}^{-1}$ & $\mathrm{~kJ} \cdot \mathrm{mol}^{-1}$ & $\mathrm{~kJ} \cdot \mathrm{mol}^{-1}$ \\
\hline 6.27 & 336.49 & 165.9 & 19.766 & & & \\
\hline 5.46 & 336.23 & 164.5 & 19.592 & & & \\
\hline 6.12 & 336.25 & 162.4 & 19.348 & & & \\
\hline average & $336.33 \pm 0.14$ & $164.3 \pm 1.8$ & $19.6 \pm 0.21$ & $269.6 / 161.2$ & $-2.13 \pm 0.6$ & $17.4 \pm 0.6$ \\
\hline
\end{tabular}

${ }^{a}$ Uncertainties are one standard deviation, $p=101325 \mathrm{~Pa} .{ }^{b}$ Estimated as the sum of the heat capacity of the anhydrous form and the heat capacity of $1 \mathrm{~mol}$ of liquid/solid water; $75.3 / 36.6 \mathrm{~J} \cdot \mathrm{mol}^{-1} \cdot \mathrm{K}^{-1}$.

Table 7B. Fusion Enthalpy of Anhydrous Imidazo[1,2-a $]$ pyrazine

\begin{tabular}{|c|c|c|c|c|c|c|c|c|}
\hline \multirow[b]{2}{*}{ sample } & \multirow[b]{2}{*}{ onset } & \multirow[b]{2}{*}{$\Delta_{\mathrm{cr}}^{\mathrm{l}} H_{\mathrm{m}}(T)$} & \multirow[b]{2}{*}{ onset } & \multicolumn{2}{|c|}{$\Delta_{\mathrm{cr}}^{1} H_{\mathrm{m}}\left(T_{\text {fus }}\right)$} & \multirow[b]{2}{*}{$C_{\mathrm{p}}(\mathrm{l}) / C_{\mathrm{p}}(\mathrm{cr})$} & \multirow[b]{2}{*}{$\Delta_{\mathrm{cr}}^{1} C_{\mathrm{p}} \cdot \Delta T$} & \multirow[b]{2}{*}{$\Delta_{\mathrm{cr}}^{1} H_{\mathrm{m}}(298 \mathrm{~K})$} \\
\hline & & & & measured & adjusted $^{a}$ & & & \\
\hline$\overline{\mathrm{mg}}$ & $\mathrm{K}$ & $\mathrm{J} / \mathrm{g}^{-1}$ & $\mathrm{~K}$ & \multicolumn{2}{|c|}{$\overline{\mathrm{kJ}} \cdot \mathrm{mol}^{-1}$} & $\mathrm{~J} \cdot \mathrm{mol}^{-1} \cdot \mathrm{K}^{-1}$ & $\mathrm{~kJ} \cdot \mathrm{mol}^{-1}$ & $\mathrm{~kJ} \cdot \mathrm{mol}^{-1}$ \\
\hline 13.99 & 334.19 & 5.29 & 360.0 & 14.4 & & & & \\
\hline 9.2 & 333.98 & 6.9 & 358.9 & 16.0 & & & & \\
\hline 12.4 & 334.04 & 6.2 & 358.8 & 13.7 & & & & \\
\hline average & $334.1 \pm 0.1$ & $6.12 \pm 0.8$ & $359.2 \pm 0.6$ & $14.7 \pm 1.2$ & $15.3 \pm 1.3$ & $194.3 / 121.8$ & $-2.6 \pm 0.8$ & $12.7 \pm 1.5$ \\
\hline
\end{tabular}

${ }^{a}$ Fraction of hydrate, $(6.12 \pm 0.8) /(164.3 \pm 1.8)=0.037 \pm 0.005$; fraction of anhydrous, $0.963 \pm 0.005$ 


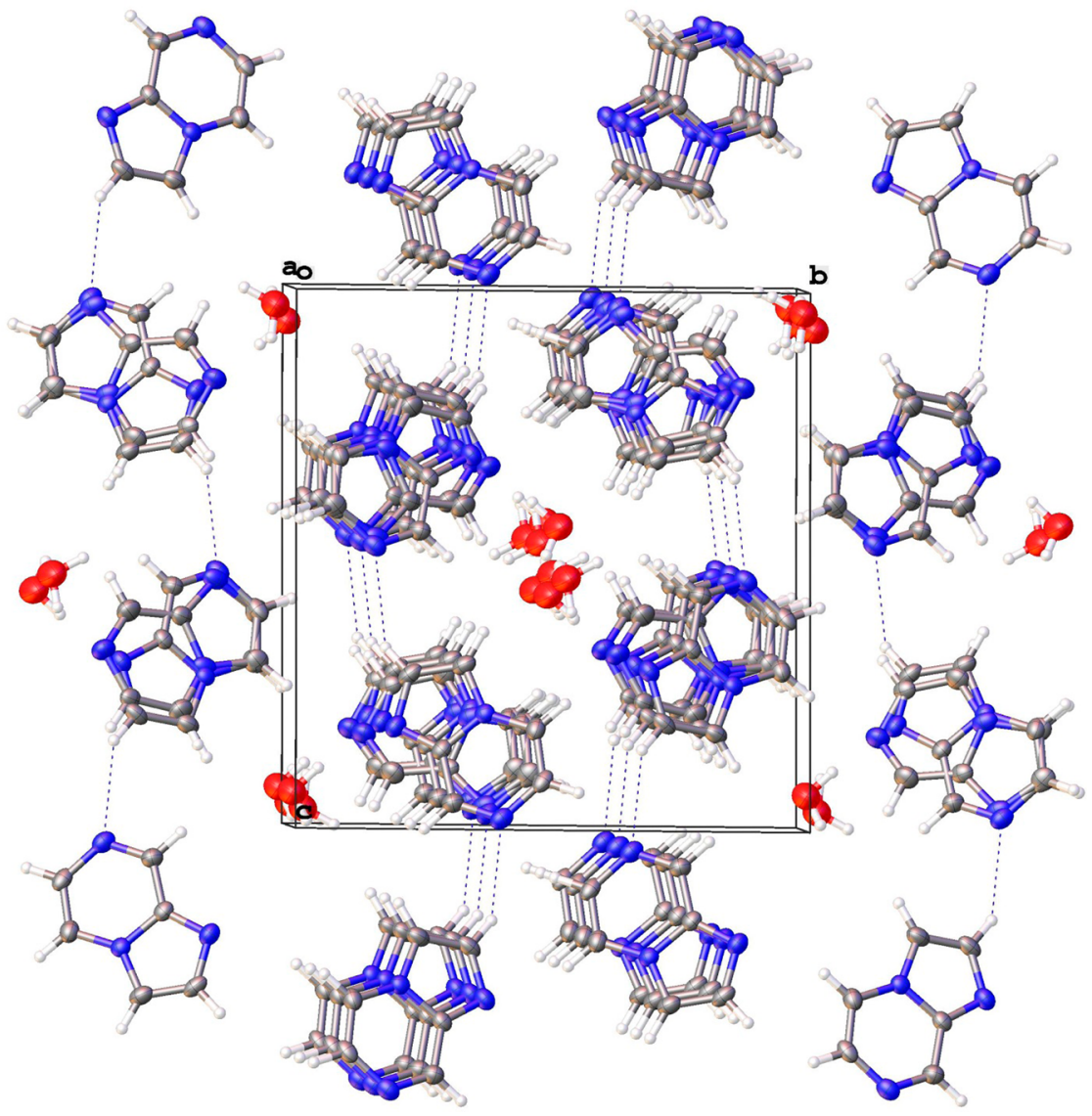

Figure 5. Disordered crystal structure of imidazo[1,2-a]pyrazine hydrate.

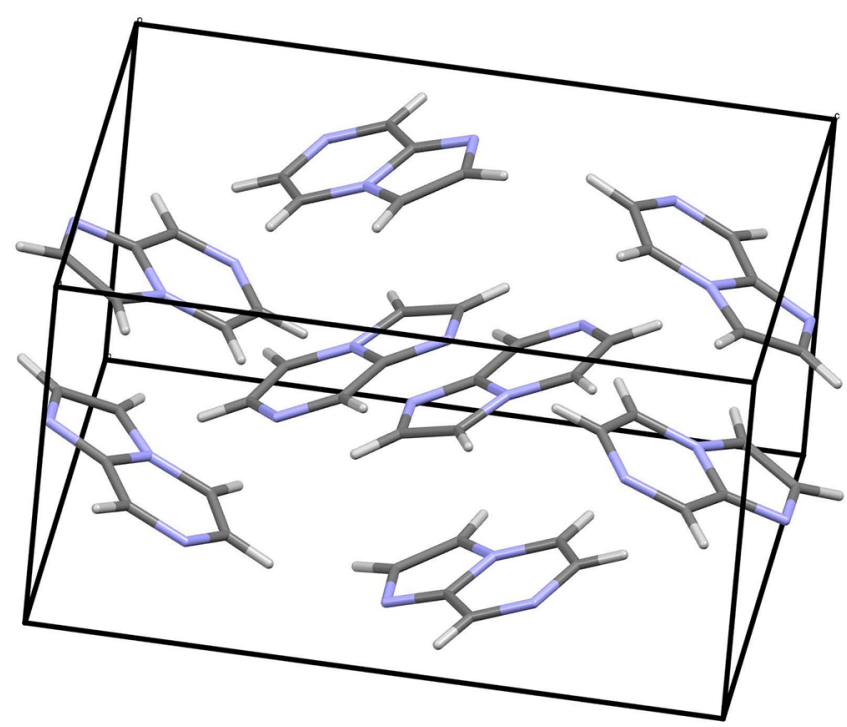

Figure 6. Packing in the unit cell of anhydrous imidazo $[1,2-a]$ pyrazine.

$3.418 \AA$ apart with centroid to centroid distance of the two benzene rings of the heterocycle, $3.663 \AA$ apart. Additional details of the structure are also provided in the Supporting Information Figure S4 and Tables S21-S26.

\section{CONCLUSION}

Although many of the materials with large dipole moments show evidence of $\pi-\pi$ stacking in the solid state, this criterion does not seem to be satisfied by the packing observed in

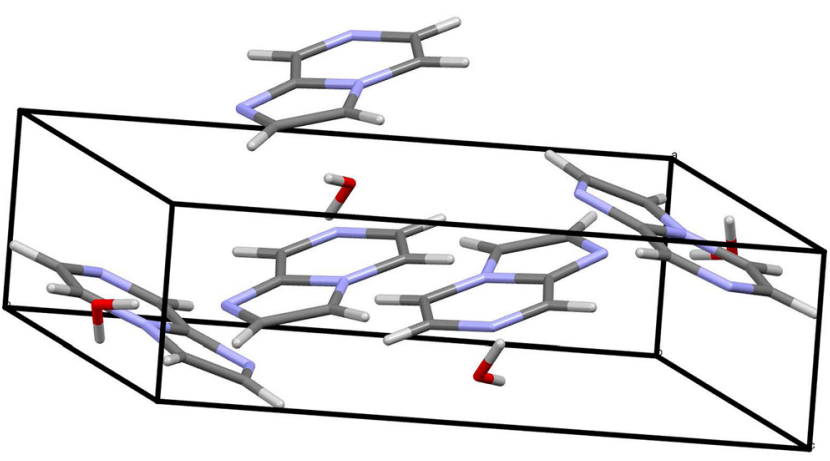

Figure 7. Packing of imidazo[1,2-a]pyrazine hydrate.

imidazo $[1,2-a]$ pyrazine. The situation in the liquid phase may differ. However, $\pi-\pi$ stacking in the solid state does not appear to be a necessary criterion for the enhanced polarity exhibited by this group of molecules. Even in cases where $\pi-\pi$ stacking is observed, there appears to be no consistency in how the molecules stack. In phthalazine, stacking is such that only the benzenoid portions of the two molecules are overlapping, whereas in the hydrate of imidazo[1,2-a]pyrazine, it is the fivemembered ring of one molecule $\pi$ stacked on the benzenoid portion of a second molecule. In benzo[c]cinnoline, $\pi-\pi$ stacking occurs mainly between the biphenyl portions of the two molecules. The nitrogen atoms of the two molecules are pointing in opposite directions. As a result, it is difficult to rationalize a constant enthalpy of interaction given such different structural arrangements. ${ }^{28}$ Nevertheless, on the basis of the vaporization enthalpy results, imidazo $[1,2-a]$ pyrazine must also 


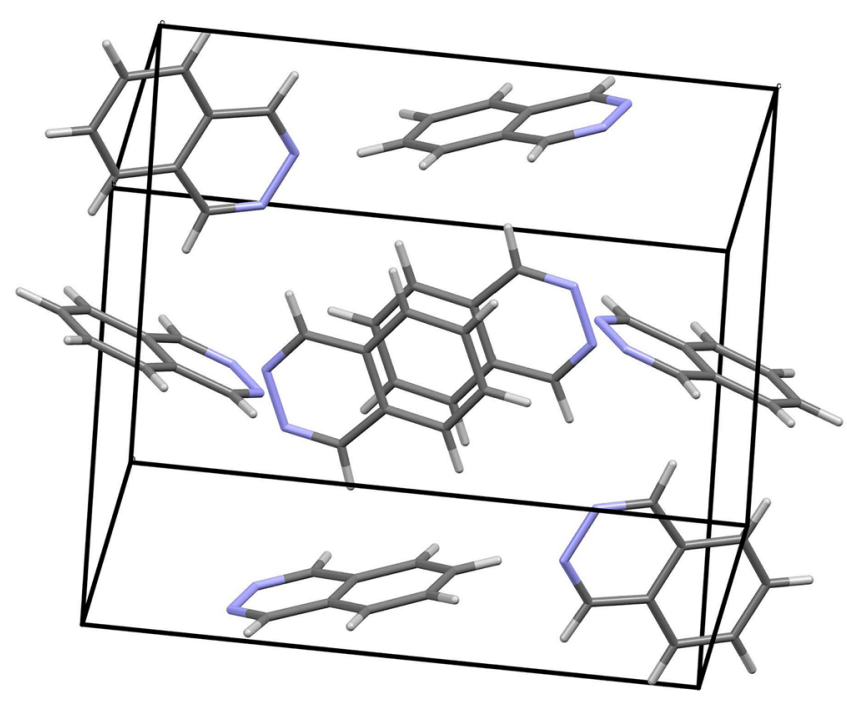

Figure 8. Packing in the unit cell of phthalazine.

be classified as a member of the group of polar molecules. What continues to be poorly understood is the reason why substances that vary significantly in polarity, as characterized by dipole moments from $0 \mathrm{D}$ to $3.0 \mathrm{D}$, correlate successfully with each other, whereas those in excess of 3.0 D likewise correlate with each other, but differ from the former by a relatively constant difference of $(6.9 \pm 0.3) \mathrm{kJ} \cdot \mathrm{mol}^{-1}$.

\section{ASSOCIATED CONTENT}

\section{S Supporting Information}

The Supporting Information is available free of charge on the ACS Publications website at DOI: 10.1021/acs.jced.5b00606.

Tables of the experimental retention times and crystallographic figures and tables referred to in the text. (PDF)

\section{AUTHOR INFORMATION}

\section{Corresponding Author}

*E-mail: jsc@umsl.edu.

\section{Funding}

This work has been supported by the German Science Foundation (DFG) in the frame of the priority program SPP 1807 "Control of London dispersion interactions in molecular chemistry”. A.S. gratefully acknowledges a research scholarship from Deutsche Akademische Austauschdienst (DAAD).

\section{Notes}

The authors declare no competing financial interest.

\section{REFERENCES}

(1) Lipkind, D.; Rath, N.; Chickos, J. S.; Pozdeev, V. A.; Verevkin, S. P. The Vaporization Enthalpies of 2- and 4-(N,N-Dimethylamino)pyridine, 1,5- Diazabicyclo[4.3.0]non-5-ene, 1,8-Diazabicyclo[5.4.0]undec-7-ene, Imidazo[1,2-a]pyridine and 1,2,4-Triazolo[1,5-a]pyrimidine by Correlation-Gas Chromatography. J. Phys. Chem. B 2011, 115, 8785-8796.

(2) Verevkin, S. P.; Emel'yanenko, V. N.; Notario, R.; Roux, M. V.; Chickos, J. S.; Liebman, J. F. Rediscovering the Wheel. Thermochemical Analysis of Energetics of the Aromatic Diazines. J. Phys. Chem. Lett. 2012, 3, 3454-3459.

(3) Lipkind, D.; Plienrasri, C.; Chickos, J. S. A Study of the Vaporization Enthalpies of Some Substituted Imidazoles and Pyrazoles by Correlation gas Chromatography. J. Phys. Chem. B 2010, 114, 16959-16967.
(4) WHO Model Lists of Essential Medicines. http://www.who.int/ medicines/publications/essentialmedicines/en/index.html (accessed September 3, 2015).

(5) Huang, L.-H.; Zheng, Y.-F.; Lu, Y.-Z.; Song, C.-J.; Wang, Y.-G.; Yu, B.; Liu, H.-M. Synthesis and biological evaluation of novel steroidal $[17,16-d][1,2,4]$ triazolo $[1,5-$ a $]$ pyrimidines. Steroids 2012, 77, $710-715$

(6) Gueiffier, A.; Mavel, S.; Lhassani, M.; Elhakmaoui, A.; Snoeck, R.; Andrei, G.; Chavignon, O.; Teulade, J.-C.; Witvrouw, M.; Balzarini, J.; De Clercq, E.; Chapat, J.-P. Synthesis of Imidazo[1,2-a]pyridines as Antiviral Agents. J. Med. Chem. 1998, 41, 5108-5112.

(7) Hemasritlatha, S.; Sruthi, K.; Manjula, A.; Babu, H.; Rao, B. V. Synthesis and anti- inflammatory acitivity of imidazo[1,2-a]pyridinyl/ pyrazinyl benzamides and acetamides. Indian J. Chem. 2012, 51B, 981-987.

(8) Moraski, C. G.; Markley, L. D.; Cramer, J.; Hipskind, P. A.; Boshoff, H.; Bailey, M. A.; Alling, T.; Ollinger, J.; Parish, T.; Miller, M. J. Advancement of Imidazo[1,2-]pyridines with Improved Pharmacokinetics and nM Activity vs. ACS Med. Chem. Lett. 2013, 4, 675-679.

(9) Burger, M. T.; Pecchi, S.; Wagman, A.; Ni, Z.; Knapp, M.; Hendrickson, T.; Atallah, G.; Pfister, K.; Zhang, Y.; Bartulis, S.; Frazier, K.; Ng, S.; Smith, A.; Verhagen, J.; Haznedar, J.; Huh, K.; Iwanowicz, E.; Xin, X.; Menezes, D.; Merritt, H.; Lee, I.; Wiesmann, M.; Kaufman, S.; Crawford, K.; Chin, M.; Bussiere, D.; Shoemaker, K.; Zaror, I.; Maira, S.; Voliva, C. F. Identification of NVP-BKM120 as a Potent, Selective, Orally Bioavailable Class I PI3 Kinase Inhibitor for Treating Cancer. ACS Med. Chem. ACS Med. Chem. Lett. 2011, 2, 774.

(10) González, S. M.; Hernández, A. I.; Rodríguez-Arístegui, C. V. S.; Alvarez, R. M.; García, A. B.; Lorenzo, M.; Rivero, V.; Oyarzabal, J.; Rabal, O.; Bischoff, J. R.; Albarrán, M.; Cebriá, A.; Alfonso, P.; Link, W.; Fominaya, J.; Pastor, J. Imidazo[1,2-a]pyrazines as novel PI3K inhibitors. Bioorg. Med. Chem. Lett. 2012, 22, 1874-78.

(11) González, S. M.; Hernández, A. I.; Rodríguez-Arístegui, C. V. S.; Lorenzo, M. M.; Rodríguez, A.; Rivero, V.; Martín, J. I.; Saluste, C. G.; Ramos-Lima, F.; Cendón, E.; Cebrián, D.; Aguirre, E.; Gomez-Casero, E.; Albarrán, M.; Alfonso, P.; García-Serelde, B.; Oyarzabal, J.; Rabal, O.; Mulero, F.; Gonzalez-Granda, T.; Link, W.; Fominaya, J.; Barbacid, M.; Bischoff, J. R.; Pizcueta, P.; Pastor, J.; Varela, C. Identification of ETP-46321, a potent and orally bioavailable PI3K a, $\delta$ inhibitor. Bioorg. Med. Chem. Lett. 2012, 22, 3460-3466.

(12) González, S. M.; Hernández, A. I.; Varela, C.; Lorenzo, M.; Ramos-Lima, F.; Cendón, E.; Cebrián, D.; Aguirre, E.; Gomez-Casero, E.; Albarrán, M. I.; Alfonso, P.; García-Serelde, B.; Mateos, G.; Oyarzabal, J.; Rabal, O.; Mulero, F.; Gonzalez-Granda, T.; Link, W.; Fominaya, J.; Barbacid, M.; Bischoff, J. R.; Pizcueta, P.; BlancoAparicio, C.; Pastor, J. Rapid identification of ETP-46992, orally bioavailable PI3K inhibitor, selective versus mTOR. Bioorg. Med. Chem. Lett. 2012, 22, 5208-5214.

(13) De Vries Reilingh, D. N.; Rettschnick, R. P. H.; Hoytink, G. J. Dimerization of 9,10-Diazaphenanthrene. J. Chem. Phys. 1971, 54, 2722-2727.

(14) van der Meer, H. The Crystal Structure of 9,10-Diazaphenanthrene. Acta Crystallogr., Sect. B: Struct. Crystallogr. Cryst. Chem. 1972, B28, 367-370.

(15) Kulikov, D.; Verevkin, S. P.; Heintz, A. Enthalpies of Vaporization of a Series of Linear Aliphatic Alcohols. Experimental Measurements and Application of the ERAS-Model for Their Prediction. Fluid Phase Equilib. 2001, 192, 187-207.

(16) Verevkin, S. P. Pure Component Phase Changes Liquid and Gas. In Experimental Thermodynamics: Measurement of the Thermodynamic Properties of Multiple Phases, 7; R.D. Weir, R. D., De Loos, Th. W., Eds.; Elsevier B.V.: Radarweg, The Netherlands, 2005.

(17) Chickos, J. S.; Hosseini, S.; Hesse, D. G.; Liebman, J. F. Heat Capacity Corrections to a Standard State: A Comparison of New and Some Literature Methods for Organic Liquids and Solids. Struct. Chem. 1993, 4, 271-277.

(18) Chickos, J. S.; Hesse, D. G.; Liebman, J. F. A Group Additivity Approach for the Estimation of Heat Capacities of Organic Liquids and Solids at 298 K. Struct. Chem. 1993, 4, 261-268. 
(19) Acree, W., Jr.; Chickos, J. S. Phase Transition Enthalpy Measurements of Organic and Organometallic Compounds. Sublimation, Vaporization and Fusion Enthalpies From 1880 to 2010. J. Phys. Chem. Ref. Data 2010, 39, 1-940.

(20) Gobble, C.; Chickos, J. S. A Comparison of Results by Correlation Gas Chromatography With Another Gas Chromatographic Retention Time Technique. The Effects of Retention Time Coincidence On Vaporization Enthalpy and Vapor Pressure. J. Chem. Eng. Data 2015, 60, 2739.

(21) Peacock, L. A.; Fuchs, R. Enthalpy of Vaporization Measurements by Gas Chromatography. J. Am. Chem. Soc. 1977, 99, 55245525.

(22) Sabbah, R.; Xu-wu, A.; Chickos, J. S.; Planas Leitao, M. L.; Roux, M. V.; Torres, L. A. Reference materials for calorimetry and differential analysis. Thermochim. Acta 1999, 331, 93-204.

(23) Lipkind, D.; Chickos, J. S.; Liebman, J. F. Study of the Anomalous Behavior of 1,2- Diazines by Correlation Gas Chromatography. J. Chem. Eng. Data 2010, 55, 1628-35.

(24) Tjebbes, J.; et al. The Heats of Combustion and Formation of the Three Diazines and Their Resonance Energies. Acta Chem. Scand. 1962, 16, 916-921.

(25) Lipkind, D.; Chickos, J. S. An examination of the vaporization enthalpies and vapor pressures of pyrazine, pyrimidine, pyridazine and 1,3,5-triazine. Struct. Chem. 2009, 20, 49-58.

(26) Steele, W. V.; Chirico, R. D.; Nguyen, A.; Knipmeyer, S. E. Vapor pressures, high temperature heat capacities, critical properties, derived thermodynamic functions, and barriers to methyl-group rotation for six dimethylpyridines. J. Chem. Thermodyn. 1995, 27, 311-334.

(27) Steele, W. V.; Archer, D. G.; Chirico, R. D.; Collier, W. B.; Hossenlopp, I. A.; Nguyen, A.; Smith, N. K.; Gammon, B. The Thermodynamic Properties of Quinoline and Isoquinoline. J. Chem. Thermodyn. 1988, 20, 1233-1264.

(28) Kostjukov, V. V.; Khomytova, N. M.; Hernandez Santiago, A. A.; Cervantes Tavera, A.-M.; Alvarado, J. S.; Evstigneev, M. P. Parsing of the free energy of aromatic-aromatic stacking interactions in solution. J. Chem. Thermodyn. 2011, 43, 1424-1434. 